\title{
NEW RESEARCH LABORATORIES OF HILGER AND WATTS, LTD.
}

\begin{abstract}
CINCE the Second World War, the idea conjured $S$ up by the expression 'scientific instrument' has changed. It is well known that electronics has invaded every field of measurement, including the optical field, but it is less realized that instruments have tended to become larger. They have done so not only because of the addition of electronic units but also because this in turn has made possible com. plexities that would previously not have been considered.
\end{abstract}

To take one example, the quality of steel during the War was controlled by using the large quartz spectrograph, the photographic plates exposed in which carried the spectra of some twenty samples together with calibration spectra. The blackness of the lines at the appropriate places was measured with a microphotometer, reading from a galvanometer scale. Nowadays, when a charge of 70 tons of steel may be prepared and poured in $12 \mathrm{~min}$., the foreman must have the analysis of a sample in as few minutes as possible if he is to have time to take any necessary action to rectify the charge. The automatic spectrograph or 'polychromator' takes up three or four times the space of the equipment previously used, but it provides an analysis of as many as thirty elements in about $3 \mathrm{~min}$. in a typical case. To determine the carbon, phosphorus and sulphur in a sample, instruments are made that use the vacuum ultra-violet region of the spectrum as well as the air-penetrating ultra-violet region.

This trend, as well as the rise in numbers of instruments required, has induced Messrs. Hilger and Watts, Ltd., to build a new research laboratory at Camden Town, London, N.W.1, as an extension of their headquarters building there. Since the comprehensive damage to the factory caused by a flying bomb in 1944, research on instruments for analytical and kindred purposes has been carried out in rooms spread over the factory and adjacent outbuildings.
(This does not apply to the research on surveying, photogrammetric and engineers' measuring instruments being done at the firm's Camberwell factory.)

The use of the new building was inaugurated by Sir George Thomson on December 15. The ceremony took the form of visiting the laboratories, in which normal work was in progress, and a luncheon attended by some 150 guests. The guesta were drawn from among university physical and chemical departments, medical and government laboratories, and the research laboratories of industry.

Sir George was introduced by the chairman of the Company, Mr. G. A. Whipple, who is the present master of the Company of Scientific Instrument Makers. Mr. Whipple referred to the growth of the firm, which now has more than 2,000 employees, an associated company in the United States, and branch offices in Canada and Western Germany. He thanked the architect (Mr. J. Francis Smith), the builders (Messrs. Mullen and Lumsden), and the quantity surveyor (Mr. D. T. C. Thompson).

Sir George then proposed the toast of the Company and the new laboratories. He spoke of the 'pure' research worker's debt to industry, in that the needs of industry for large and complex instruments, which had to be reliable, encouraged the scientific instrument firms, which in turn could provide better instruments for pure research. Hilger and Watts was such a firm: "Twyman proved to industry the value of spectroscopic analysis. The demand so created made expansion possible, and its latest stage we are inaugurating to-day. From this, we benefit by the increased scale of the firm and by the great improvement this has made possible in design, which has given this great firm the enormous prestige it now holds throughout the world and which we are happy to be here to-day to celebrate".

Dr. A. C. Menzies, the firm's director of research, said in his reply that he had been concerned in his

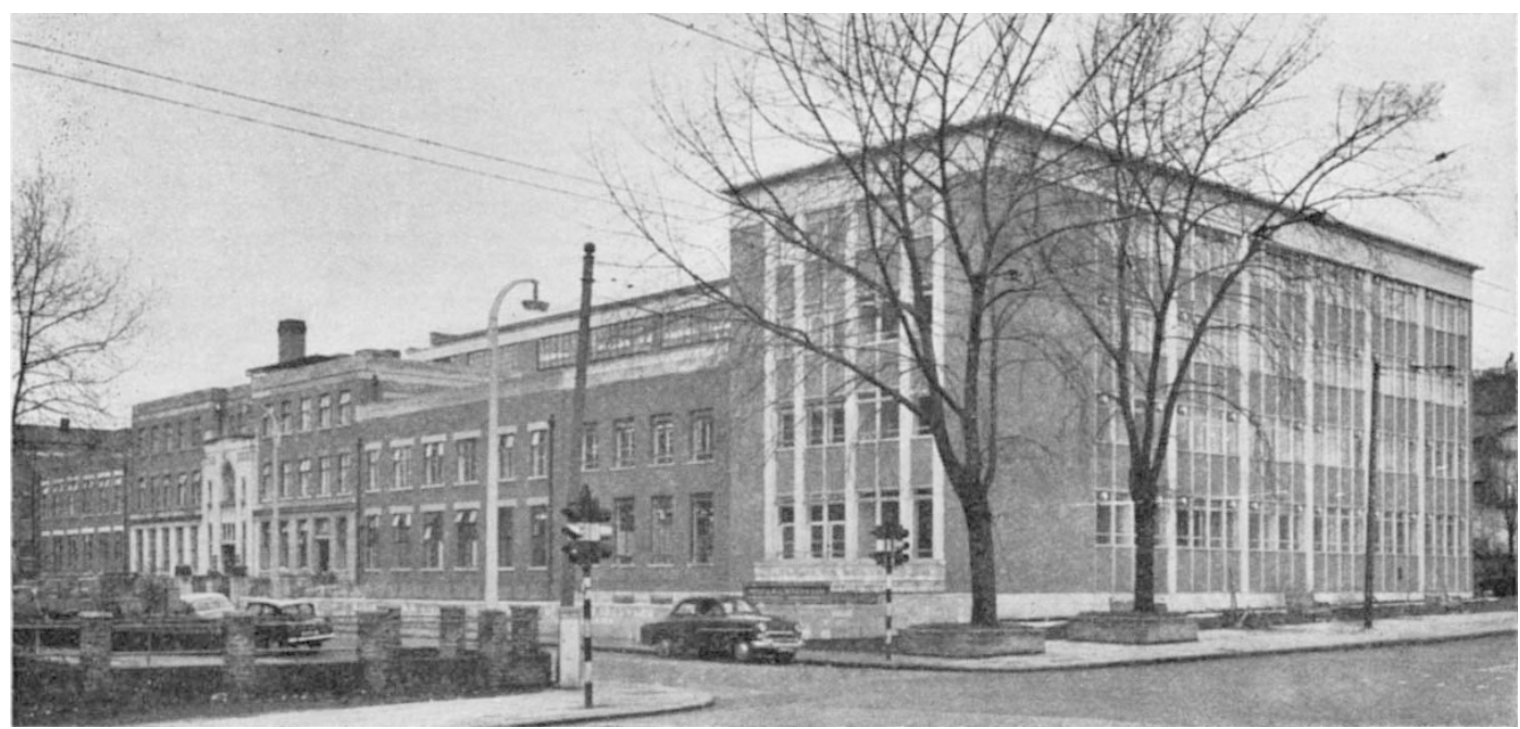

Fig. 1. New Research Laboratory of Hilger and Watts, Ltd. 
life with the building of three laboratories. However, it was only with the third of them, this new laboratory at Camden Town, that he had had the pleasure of contributing little but the expression of his requirements. This was the result of having good colleagues. He had worked with Sir George Thomson during the War, and it was at Sir George's instance that he had come to Hilger and Watts to succeed Mr. Frank Twyman. Sir George had added with a smile that the job was an easy one, so Dr. Menzies had frequently overcome difficulties since then by reminding himself that they could not exist. When he started with the firm, he turned one of the smallest rooms in an outside building into a dark room; "it had the advantage that water was laid on already". Such conditions made him resolve to work for a satisfactory, attractive place where his colleagues could work comfortably and effectively. Now they had it.

After the luncheon, the guests toured the laboratories and saw research being undertaken into spectroscopic analysis by emission, $\mathrm{X}$-ray diffraction and X-ray fluorescence; infra-red absorption; optical design; absorption spectroscopy; optical instruments for the control of chemical processes; electron-spin resonance spectrometry ; and generators for ares and sparks.

N. J. Goopman

\section{SCIENTIFIC RESEARCH IN AUSTRALIA}

$\mathrm{T}$ HE twelfth annual report of the Commonwealth (of Australia) Scientific and Industrial Research Organization, covering the year anded June 30, 1960, departs considerably from the form of previous years*. To facilitate its presentation to Parliament early in the 1960 Budget sitting, the chapters describing detailed technical matters characterizing previous reports have been replaced by a brief account of the more important developments during the year, and the details are to be published separately as a research review. The bulk of the present report consists of lists of published papers, and the membership of the Advisory Council, State Committees and staff and finance.

Of the expenditure of $£ 9,489,741, £ 8,862,160$ was on normal research activities and $£ 144,600$ on grants to outside bodies. Among new arrangements with the universities are noted support of an investigation by the Department of Zoology, University of Melbourne, into the effects of chromosomal inversion on viability of grasshoppers; collaboration with the University of New South Wales in an investigation of tritium-labelling techniques ; continuation of research at the Australian National University into aggregation and denaturation of protein ; and an extended loan to the Electrical Engineering Department, University of Tasmania, of the differential analyser developed by the Mathematical Instruments Section. Construction of the giant radiotelescope at Parkes, New South Wales, for the Division of Radiophysics is expected to be complete early in 1961 .

Among the more important developments of the year noted in the chapter "Progress in Research" are the solution of serious problems preventing the development by irrigation of large areas of potentially fertile but intractable soils in the Riverina by using low concentrations of gypsum in the irrigation water to make the surface clays permeable. A study of the characteristics of coats of cattle in the tropies showed that gain in weight can be predicted much more accurately from the type of coat than from actual records of past gain in weight. A new process by which cheese is matured in a plastic wrapping has been adapted for Australian conditions, and a new kind of anti-fungal compound, 'Pisatin', has been isolated from peas. A strain of cocksfoot grass, introduced from Brignolles in France, has proved outstandingly productive as a component of

- Commonwealth of Australia. Twelfth Annual Report of the Commonwealth Scientific and Industrial Research Organization for the year ending 30 th June, 1960 . Pp. If +129 . (Melbourne : Common-
wealth Scientific and Industrial Research Organization, 1960.) winter pastures near Canberra and has persisted well under heavy stocking. Up to 90 per cent control of rabbits has been achieved with sodium fluoroacetate using a suitable bait; but its effective use depends on intelligent application of accurate knowledge of feeding habits and behaviour of the rabbit. Striking increases in beef production have been obtained in grazing trials with a grass-legume mixture in native spear grass country near Gladstone, and further evidence has been obtained of the primary importance of nutritional factors in determining the mortality among new-born lambs. The compounds causing certain off-flavours in butter have been identified, and most of the conditions under which these flavours develop have been recognized. Research at Crookwell has shown that sulphur is an essential constituent of the soil organic matter, and that lack of sulphur often limits the rate of build-up of soil fertility under improved pastures.

The first commorcial plant for the manufacture of fully mechanized Cheddar cheese has been installed and successfully operated, and a field experiment in North Queensland suggests that control of the cattle tick can be greatly improved both by pasture spelling and strategic dipping. Equipment has been designed to overcome the difficulty of measuring the tempera. ture of biscuits in a long conveyor-type oven due to the very limited access to the interior of the oven, and the method for producing washable non-iron effects in wool fabrics has reached commercial application. Two new statistical techniques have been developed for accurate spatial prediction of rainfall.

Polyethylene box liners have been used to increase significantly the storage life of four main varieties of apples. A new pre-steaming procedure has been developed which is greatly improving the drying of refractory timbers with a saving of 20 per cent in tho time of drying with some species. It has now been found that sugar-cane wax as it occurs on the cane consists chiefly of polymerized long-chain aldehydes, with lesser amounts of long-chain alcohols. A study has also been made of the waxes coating the tubercule and diphtheria bacteria.

Investigations of the hardening of brass have proved that alpha brass is 'ordered' after slow-cooling treatments, and that the degree of order can be considerably increased by isothermal annealing at low temperatures. X-ray methods have been further developed for the determination of the structures of large molecules, by applying a high-power $\mathrm{X}$-ray generator and by collecting intensity data at low 